\title{
Cardiometabolic risk in polycystic ovary syndrome
}

\author{
Katica Bajuk Studen ${ }^{1}$ and Marija Pfeifer ${ }^{2}$ \\ ${ }^{1}$ Nuclear Medicine Department, University Medical Centre Ljubljana, Ljubljana, Slovenia \\ ${ }^{2}$ Faculty of Medicine, University of Ljubljana, Ljubljana, Slovenia \\ Correspondence should be addressed to M Pfeifer: misa.pfeifer@gmail.com
}

\begin{abstract}
Polycystic ovary syndrome (PCOS) is a common disorder in women of reproductive age. Besides hyperandrogenism, oligomenorrhea and fertility issues, it is associated with a high prevalence of metabolic disorders and cardiovascular risk factors.

Several genetic polymorphisms have been identified for possible associations with cardiometabolic derangements in PCOS. Different PCOS phenotypes differ significantly in their cardiometabolic risk, which worsens with severity of androgen excess. Due to methodological difficulties, longer time-scale data about cardiovascular morbidity and mortality in PCOS and about possible beneficial effects of different treatment interventions is missing leaving many issues regarding cardiovascular risk unresolved.
\end{abstract}

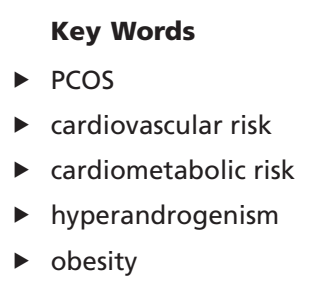

Endocrine Connections (2018) 7, R238-R251

\section{Introduction}

Polycystic ovary syndrome (PCOS) is a common disorder in women of reproductive age, with a prevalence $5-16 \%$ under different diagnostic criteria and across several ethnic groups, with exact pathogenesis still unclear $(1,2,3)$. General agreement exists now among the community of endocrinologists and gynecologists that the diagnosis of PCOS should be based on the Rotterdam criteria, which include two of the following three features: oligo-/amenorrhea, hyperandrogenism (clinical or biochemical) and polycystic ovaries on ultrasound, after exclusion of other endocrinopathies (4). These criteria have broadened the spectrum of PCOS phenotypes in contrast to those defined previously by the 1990 National Institutes of Health (NIH) criteria that required both oligo-/anovulation and clinical or biochemical hyperandrogenism for the diagnosis of PCOS (5). The Rotterdam diagnostic criteria have led to the generation of four distinct phenotypic subgroups: the 'PHO' subgroup with all three diagnostic features present; the 'HO' subgroup with hyperandrogenism and oligo-/amenorrhea, the ' $\mathrm{PH}^{\prime}$ subgroup with polycystic ovaries on ultrasound and hyperandrogenism and the 'PO' subgroup with polycystic ovaries on ultrasound and oligo-/amenorrhea.

Besides the clinical features of hyperandrogenism (hirsutism, acne, male-type baldness), oligo-/ amenorrhea and impaired fertility, PCOS patients are often insulin resistant, obese and have metabolic syndrome, with arterial hypertension, dyslipidemia, impaired glucose tolerance or frank type 2 diabetes, lowgrade inflammation and increased pro-thrombotic state (2). This high prevalence of cardiovascular risk factors in PCOS is assumed to be associated with accelerated cardiovascular disease. However, clear data from large end point trials about cardiovascular morbidity and mortality in PCOS is currently lacking, although there are plenty of data on early occurrence of subclinical, potentially reversible atherosclerosis in women with PCOS (6). The aim of this article is to explore and review current evidence that associates PCOS with cardiometabolic abnormalities and possibly an increased risk of cardiovascular disease. http://www.endocrineconnections.org https://doi.org/10.1530/EC-18-0129 (c) 2018 The authors Published by Bioscientifica Ltd

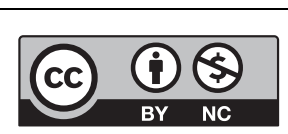

This work is licensed under a Creative Commons Attribution-NonCommercial 4.0 International License. 
Insulin resistance, metabolic syndrome, obesity and sleep disturbances in PCOS and cardiovascular risk

Insulin resistance

In PCOS patients, basal insulin secretion rates are increased, although insulin secretory responses to a glucose load are generally inadequate in comparison to healthy subjects $(7,8)$. At a tissue level, insulin resistance is present in the liver, adipose tissue and muscles of these patients. The PCOS-associated insulin resistance is selective, affecting metabolic, but not mitogenic, signaling pathways, which might explain the paradox of persistent reproductive actions of insulin in the face of systemic insulin resistance (8). In approx. $40 \%$ of women with PCOS defined by NIH criteria, impaired glucose tolerance or type 2 diabetes mellitus as consequences of insulin resistance develop by their fourth decade of life, with age and weight gain having an adverse effect on glycemic control $(9,10,11$, $12,13,14)$. Moreover, a study basing PCOS diagnosis on Rotterdam criteria reported insulin resistance in $71.4 \%$ of included subjects (15). However, insulin resistance frequency significantly differed among phenotypes, being $80.4 \%$ in the 'classic NIH phenotype' group (including the above mentioned 'PHO' and 'HO' phenotypes), $65.0 \%$ in the ovulatory group (the above mentioned ' $\mathrm{PH}$ ' phenotype) and $38.1 \%$ in the normoandrogenemic group (the above mentioned 'PO'), respectively. The classic phenotype and, to a lesser extent, the ovulatory phenotype were independently associated with insulin resistance, whereas the normoandrogenic phenotype was not. This was confirmed by another study which showed that the number of PCOS patients with homeostatic model assessment insulin resistance (HOMA-IR) index $>3.8$ was significantly higher in androgenic phenotypes in comparison to other phenotypes (16).

\section{Metabolic syndrome}

Insulin resistance is a central mechanism linking together all components of the metabolic syndrome, defined by the presence of hyperglycemia (fasting glucose levels $5.6 \mathrm{mmol} / \mathrm{L}$ or above), central obesity (increased waist circumference by population and country specific definitions), low high-density lipoprotein (HDL) cholesterol level $(<1.29 \mathrm{mmol} / \mathrm{L}$ in women), high total triglyceride level $(1.7 \mathrm{mmol} / \mathrm{L}$ or above) and elevated arterial blood pressure $(130 / 85 \mathrm{mmHg}$ or above $)(17,18)$. The prevalence of metabolic syndrome is significantly higher in PCOS population as compared to BMI-matched controls. In the United States, it is estimated to be two to three times higher than that of age-matched controls (19, $20,21)$. However, its prevalence was found to be lower in countries with lower prevalence of obesity such as Spain or Italy, ranging between 8 and $25 \%$ in women with classic PCOS $(22,23)$. Regarding the Rotterdam criteria of PCOS, metabolic syndrome prevalence was significantly higher in phenotypes ' $\mathrm{PHO}$ ' and ' $\mathrm{HO}$ ' $(29.6 \%$ and 34.5\%, respectively) compared with the other phenotypes $(10.0 \%$ in ' $\mathrm{PH}$ ' and 8.3\% in 'PO') (16).

Many conditions, mainly components of the metabolic syndrome, have been recognized as risk factors for cardiovascular disease, such as impaired glucose tolerance, type 2 diabetes mellitus, dyslipidemia, abdominal obesity and hypertension (24).

\section{Obesity}

A large proportion of women with PCOS are overweight, obese or centrally obese, with data regarding prevalence again varying across different populations (25, 26). Patients with PCOS have increased proportion of central to peripheral fat ratio when compared to controls $(27,28$, 29). Obesity, particularly of visceral origin, plays a crucial role in both development and maintenance of PCOS (30, 31) and significantly influences the severity of metabolic and cardiovascular risk profile $(32,33)$. In PCOS, obesity is a well-documented risk factor for abnormal glucose tolerance with increased rates of impaired glucose tolerance and type 2 diabetes, metabolic syndrome and dyslipidemia $(19,24,34)$.

A recent review of studies on obesity in PCOS showed that overweight and obese women with PCOS had increased fasting glucose, fasting insulin, HOMA-IR index and worsened lipid profile (35). Obesity significantly worsened all metabolic and reproductive measures except for hirsutism when compared to normal women with PCOS. Central obesity was associated with higher fasting insulin levels. This study also reported that in overweight and obese PCOS women, the fasting lipid profile worsens.

It still remains an open issue whether lean women with PCOS are at increased cardiovascular risk (24). Lean women with PCOS demonstrate intrinsic abnormalities in body fat distribution and insulin resistance (36). Even in normal-weight girls (age 15.9 \pm 1.8 years, BMI $22.7 \pm 2.3$ ) with PCOS, decreased peripheral insulin sensitivity and muscle mitochondrial dysfunction, abnormal glucose disposal, relative postprandial hyperinsulinemia and increased hepatic fat content compared to normal-weight controls were reported (37).

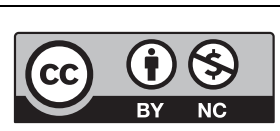

This work is licensed under a Creative Commons Attribution-NonCommercial 4.0 International License. 
PCOS patients often have lower sex-hormonebinding globulin (SHBG) levels, which could be further exacerbated with obesity (38). SHBG has been shown to be positively associated with HDL and physical fitness and negatively associated with obesity, central fat distribution, triglycerides, insulin resistance and diabetes (39).

\section{Sleep disturbances and disorders in PCOS}

There is also a growing body of evidence suggesting that sleep disturbances including obstructive sleep apnea (OSA) and excessive daytime sleepiness can be added to the list of cardiometabolic risk factors in PCOS with link between the two being complex and possibly bidirectional $(40,41)$. OSA is a relatively common and chronic sleep disorder characterized by recurrent complete (apnea) or partial (hypopnea) upper airway obstruction during sleep leading to intermittent hypoxia, cortical microarousals, sleep fragmentation, increased sympathetic neural activity, hypothalamus-pituitary-adrenal axis dysregulation, altered cytokine release and oxidative stress (42). There is also strong evidence suggesting that OSA contributes to the development of hypertension, cardiovascular disease and abnormalities in glucose metabolism (43, 44, 45). A recent meta-analysis suggests that risk of OSA is increased in adult women with PCOS. It seems that central obesity, hyperandrogenemia and insulin resistance, either alone or in concert, could be implicated in the development of OSA in women with PCOS (40). However, at present, there is scarce evidence about possible cardiometabolic improvement of OSA treatment in PCOS, although continuous positive airway pressure (CPAP) has been shown to be a promising treatment for OSA in young obese women with PCOS, with improvements in insulin sensitivity, daytime diastolic blood pressure and cardiac sympathovagal balance after 8 weeks of treatment (46). More interventional trials in PCOS patients are lacking. In the general OSA subpopulation (mostly men), there is now evidence from systematic reviews with metaanalyses that CPAP reduces blood pressure and endothelial dysfunction $(47,48,49)$. Systematic reviews with metaanalysis have also indicated that insulin resistance can be improved with CPAP use in OSA patients, thereby possibly reducing the risk of developing type 2 diabetes in nondiabetic and pre-diabetic individuals (50).

Therefore, it would seem prudent to screen PCOS patients for clinical features and symptoms associated with OSA and refer the ones at risk for further evaluation with overnight polysomnography and treatment, although the new international PCOS guidelines that are in preparation do not recommend these steps.

http://www.endocrineconnections.org https://doi.org/10.1530/EC-18-0129

(C) 2018 The authors Published by Bioscientifica Ltd

\section{Other/non-classical cardiovascular risk factors} in PCOS

PCOS is also associated with changes in circulating factors of coagulation and fibrinolysis, such as increased levels of factor VIIc, von-Willebrand's factor, thrombomodulin, D-dimer, antithrombin III and fibrinogen (51, 52). Thrombin activatable fibrinolysis inhibitor levels were reported to be higher in PCOS women (in comparison to age- and BMI-matched healthy controls) possibly contributing to hypofibrinolytic state and accelerated atherosclerosis (53).

A study evaluating oxidative stress and leukocyte adhesion (both being implicated in the etiology of chronic low-grade inflammation and early cardiovascular risk) in PCOS, an increase in the rate of reactive oxygen species and myeloperoxidase levels was reported, particularly in patients with insulin resistance. Moreover, it was shown that inflammation in PCOS induces leukocyteendothelium interactions and a simultaneous increase in interleukin-6, tumor necrosis factor (TNF) alpha, E-selectin, adhesion molecules such as intercellular adhesion molecule-1 and vascular cell adhesion molecule-1, which are all aggravated in the presence of insulin resistance (54).

Moreover, a very recent large retrospective longitudinal cohort study in the United Kingdom evaluating nonalcoholic fatty liver disease (NAFLD) rates in 63,120 women with PCOS and 121,064 age-, BMI- and location-matched control women found that women with PCOS have an increased rate of NAFLD $(\mathrm{HR}=2.23,95 \% \mathrm{CI} 1.86 \pm 2.66, P<0.001)$. The incidence of NAFLD increased with increasing androgen and decreasing SHBG levels (87). NAFLD is associated with increased mortality due to an increased risk from cardiometabolic complications and death from liver failure and hepatocellular carcinoma $(55,56)$. Similar findings in PCOS women were also reported previously by smaller studies and systematic reviews $(57,58,59)$.

In PCOS, serum advanced glycation end products (AGEs) are distinctly elevated compared with women having the isolated characteristics of the syndrome (60). It has been suggested that chronic inflammation and increased oxidative stress may be a link between the mechanisms of AGEs action and the metabolic and reproductive consequences of PCOS. High dietary AGEs intake promotes deteriorating biological effects in women with PCOS, whereas AGEs restriction seems to have beneficial impact on women's health (61).

A comprehensive meta-analysis of cardiovascular risk markers in women with PCOS that included 130 data

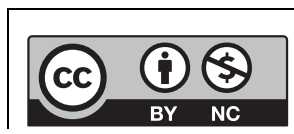

This work is licensed under a Creative Commons Attribution-NonCommercial 4.0 International License. 
sets in 11 different outcomes, has shown that women with PCOS demonstrated significantly elevated CRP, homocysteine, plasminogen activator inhibitor-I (PAII), PAI-I activity, vascular endothelial growth factor, asymmetric dimethylarginine, AGEs and lipoprotein(a) in comparison to controls, although with significant between-study heterogeneity (62). Borderline significance was detected for TNF alpha, endothelin-I and fibrinogen, whereas no significance was detected for interleukin-6. According to results of this meta-analysis, in light of the atherosclerotic process, PCOS is related not only to lowgrade chronic overall and endothelial inflammation but also to coagulation abnormalities. Moreover, in this paper, a clinical interpretation of the results was attempted based on selected published evidence which elucidated that serum concentrations of cardiovascular risk markers are not negligible, being of similar order of magnitude to those in patients with established cardiovascular disease.

\section{Hyperandrogenism and cardiovascular risk in PCOS}

Hyperandrogenism is associated with an adverse metabolic phenotype and an increased cardiovascular risk through complex and multidirectional pathways $(63,64)$. Exposure to hyperandrogenemia (either prenatally or as an adult) may influence body fat distribution, insulin resistance and other cardiometabolic risk features $(65,66)$. It was also shown that hyperandrogenemic women with PCOS have significantly higher liver fat content in comparison to normoandrogenemic PCOS and control women, which was independent of obesity and insulin resistance (67).

A study investigating different phenotypes of PCOS based on the Rotterdam criteria found that ' $\mathrm{PO}$ ' phenotype did not differ significantly from control women in respect to insulin sensitivity, and these patients were significantly less insulin resistant than 'PHO' phenotype (68). It was also shown that obese normoandrogenemic women with PCOS had a relatively mild phenotype compared with obese hyperandrogenemic women with PCOS, based on 1990 NIH criteria (69).

As part of the Study of Women Across the Nation (SWAN), an analysis which included 3297 premenopausal and perimenopausal women of different ethnic groups (white, black, Hispanic, Chinese and Japanese) showed that low SHBG and high free androgen index are strongly and consistently related to increased cardiovascular disease risk factors (higher insulin, glucose, hemostatic and inflammatory markers and more adverse lipid profile), even after controlling for body mass (39). The study concluded that androgens likely play a role in the cardiovascular risk profile of perimenopausal women.

Simultaneous measurement of serum testosterone and androstenedione represents a useful tool for predicting metabolic risk in PCOS women. A recent study has shown that serum androstenedione was a more sensitive indicator of PCOS-related androgen excess than serum total testosterone concentrations (70). Furthermore, this study demonstrated that PCOS patients with co-elevation of androstenedione and testosterone had impaired indices of insulin sensitivity compared with those with normal androgens or milder hyperandrogenemia. Moreover, multiple linear regression showed a strong negative association between serum androstenedione and insulin sensitivity. The incidence of dysglycemia according to an oral glucose tolerance test increased with the severity of androgen phenotype. Concurrent measurement of both androstenedione and testosterone discovers a PCOS cohort that appears to be at the highest metabolic risk.

However, a recent large prospective population-based cohort study in postmenopausal women from Rotterdam municipality, who had been free of cardiovascular disease at study entry, found no association between higher androgen levels in postmenopausal women and incident stroke, coronary heart disease or composite cardiovascular disease events, after adjustment for cardiovascular risk factors (71). Authors concluded that atherosclerosis burden among postmenopausal women might be caused largely by adverse cardiovascular risk factors, and hyperandrogenism per se might not be a risk factor for cardiovascular disease after menopause. The limitation of this study was rather small number of PCOS cases identified in the cohort of 2578 women (out of 272 with the history of irregular menses at 25 years of age only 106 also had testosterone or free androgen index levels in the highest quartile) and the possibility of selection bias as women with PCOS who had developed cardiovascular disease before the menopause or age 55 years were not eligible for the study.

\section{Genetic variants possibly affecting cardiovascular risk in PCOS}

PCOS and its different phenotypes result from complex interactions between multiple genetic predisposing variants and environmental and lifestyle factors (2). Possible associations between several genetic polymorphisms in PCOS in relation to its metabolic http://www.endocrineconnections.org https://doi.org/10.1530/EC-18-0129 (c) 2018 The authors Published by Bioscientifica Ltd
This work is licensed under a Creative Commons Attribution-NonCommercial 4.0 International License. 
complications and possible cardiovascular risk have been investigated. In a study in North India, presence of metabolic syndrome or related metabolic derangements was found to be high in the family members of women with PCOS (72). In Spanish population, some of the calpain 10 (CAPN10) gene polymorphisms (this gene has been associated with the presence of metabolic syndrome in PCOS and type 2 diabetes) were found to be related to insulin resistance phenotypes (73). Also, a correlation between PAI-I promoter $4 \mathrm{G} / 5 \mathrm{G}$ polymorphism and metabolic/proinflammatory factors in PCOS was reported (52).

In another report, the TAAAA repeat polymorphisms in the $S H B G$ gene were studied. Although it was not shown to be a major determinant of the PCOS status, it influenced serum SHBG levels in PCOS patients. Moreover, a strong negative association was shown between serum SHBG and CRP, an established risk factor of cardiovascular disease and a marker of low-grade inflammation, typical of atherogenesis. This may be one of the pathways by which low SHBG levels affect cardiovascular risk (74).

In Chinese population, the platelet-activating factor acetylhydrolase (PAF-AH) gene polymorphisms in PCOS were analyzed. Increased plasma PAF-AH and apoB-PAF-AH activities in patients with $\mathrm{H}$ allele of $\mathrm{R} 92 \mathrm{H}$ variant of the $P A F-A H$ gene were reported to be associated with changes in plasma lipoprotein levels, insulin resistance, gaining weight and thus could be involved in the pathogenesis of PCOS and the increased risk of future cardiovascular disease (75).

Some studies did not confirm expected associations. In young Turkish patients, gene polymorphism of interleukin-6 (IL6) -174 G>C was found to be a risk factor for PCOS; however, no relationship was found between the cardiovascular risk factors and IL6 -174 G>C gene and apolipoprotein E gene polymorphism in PCOS subjects $(76,77)$. In another study, an association between the MTHFR C677T gene polymorphism (which is a common genetic abnormality leading to hyperhomocysteinemia) and the development of metabolic syndrome in PCOS was not confirmed (78).

In research of cardiovascular disease, the candidatewide association study showed that no loci were definitively identified with PCOS after strict correction for multiple testing, suggesting that cardiometabolic loci are not major risk factors underlying the susceptibility to PCOS (79). It is important to recognize that further research in this area is to be expected in the next years including larger sample sizes, which will help to further elucidate possible associations.

http://www.endocrineconnections.org https://doi.org/10.1530/EC-18-0129

() 2018 The authors Published by Bioscientifica Ltd

\section{Subclinical and clinical cardiovascular disease during the lifecourse of PCOS patients}

\section{Early subclinical atherosclerotic disease in PCOS patients}

Many studies have confirmed an association between PCOS and early, subclinical, reversible forms of vascular disease $(80,81,82,83,84)$. It was shown that even young, normal-weight, non-dyslipidemic, non-hypertensive women with PCOS have an early impairment of endothelial structure and function (85); a finding that was later confirmed by meta-analysis of studies on endothelial dysfunction in PCOS as measured by flow-mediated dilation of the brachial artery (86). The meta-analysis on intima-media thickness of carotid arteries, another marker of subclinical atherosclerosis, has shown significantly increased values in women with PCOS compared with women without PCOS suggesting that women with PCOS are at a greater risk of premature atherosclerosis, which emphasizes the importance of screening and monitoring cardiovascular disease (CVD) risk factors in women with PCOS (87). Endothelial dysfunction in PCOS was found to be associated with higher levels of androgens and with insulin resistance $(88,89)$. This was observed even at very early ages, and with a trend of deterioration of endothelial function from lean to overweight and obese PCOS women, with excess visceral fat accumulation being a very important predictor of atherosclerosis in PCOS (32, $90,91)$, although not all studies are consistent (92). In a similar study evaluating PCOS patients in different age groups (<20, 20-23.9, 24-28, >28 years), it was shown that with higher age insulin resistance increases in obese but not in lean and overweight women with PCOS (14). This study thus indicates that it is possible that women with PCOS that do not become obese may exhibit a better metabolic profile during their reproductive years.

Furthermore, besides endothelial dysfunction, PCOS women older than 30 years irrespective of BMI were found to have higher waist-to-hip ratio, systolic and diastolic blood pressure, total and LDL cholesterol, triglycerides and also ratios of total cholesterol/HDL cholesterol and triglycerides/HDL cholesterol, respectively (93).

\section{Clinical cardiovascular disease in PCOS patients}

A very recent large national register-based study in Denmark that included 18,112 women with PCOS and 52,769 control women reported higher event rates

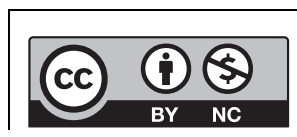

This work is licensed under a Creative Commons Attribution-NonCommercial 4.0 International License. 
of cardiovascular disease including hypertension and dyslipidemia in relatively young PCOS patients compared to controls. The age at inclusion was median (quartiles) 29 (23-35) years, follow-up was 11.1 (6.9-16.0) years and the median age at diagnosis of cardiovascular disease was 35 (28-42) years in PCOS Denmark vs 36 (30-43) years in controls $(P<0.001)$. Obesity, diabetes, infertility and previous use of oral contraceptives were associated with increased risk of development of cardiovascular disease in PCOS. Interestingly, no relation between total and free testosterone, and SHBG levels and cardiovascular disease was detected in the subgroup analysis of PCOS women in whom the biochemical data were available (94). In another study, middle-aged women with PCOS were found to be at increased risk of metabolic cardiovascular syndrome and had increased coronary artery and aortic calcification compared with controls, independently of obesity (84).

In 143 women aged 60 years or younger that underwent coronary angiography, those with more extensive coronary artery disease were more likely to have polycystic ovaries on ultrasonography than were those with less extensive disease (95). Increased coronary artery calcification in PCOS women in comparison to obese or non-obese women of similar age was also reported by another study (96).

The Nurses's Health Study included 82,439 female nurses who provided information in 1982 on prior menstrual regularity and were followed through 1996. It showed that women reporting irregular or very irregular cycles had an increased risk for nonfatal or fatal coronary heart disease with age-adjusted relative risks 1.25 and 1.67, respectively, which remained significant even after adjustment for BMI and several potential confounders. Increase in overall stroke risk and in ischemic stroke risk associated with very irregular cycles was unsignificant (97).

A study of 786 women who received a diagnosis of PCOS in the United Kingdom before 1979 and were traced to investigate the long-term consequences of the syndrome 31 years later showed that in comparison to control group women with a history of PCOS had higher levels of several cardiovascular risk factors including diabetes, hypertension, raised plasma cholesterol and BMI $>30$. Mortality and morbidity from coronary heart disease did not differ significantly between the women with PCOS and comparison groups (98).

A large cohort of 15,005 pregnant women recruited from the Kaiser Foundation Health Plan in California between 1959 and 1966 were matched to California Vital Status files annually until 2007 to identify deaths due to overall cardiovascular disease and subsets of coronary heart disease. Compared with women with regular cycles, women with irregular cycles had an increased risk for coronary heart disease mortality; however, the association was not statistically significant after adjustment for BMI. There was a nonsignificant increase in cardiovascular disease mortality (99).

Another study that used data from claims of the Taiwan National Health Insurance, identified 8048 women aged 15-49 years diagnosed with PCOS and 32,192 women without the syndrome as controls. After a mean follow-up period of 5.9 years, the overall incidence of coronary artery disease was found to be $63 \%$ higher in women with PCOS. The incidence of coronary artery disease increased further in those with cardiometabolic comorbidities (100).

In a small, longitudinal study of PCOS $(N=25)$ that followed women 21 years after the diagnosis (aged 61-79 at the time of analysis), it was shown that in comparison to the control group, PCOS women had a higher prevalence of hypertension and higher triglycerides (101). Myocardial infarction, stroke, diabetes, cancer and mortality prevalence were similar to age-matched controls. The previously mentioned large prospective population-based cohort study in postmenopausal women from Rotterdam could also not show increased morbidity and mortality from cardiovascular disease in the subcohort of women with PCOS, after adjusting for cardiovascular risk (71).

Another meta-analysis of five controlled observational studies published between 2000 and 2008 showed a relative risk for (non-)fatal coronary heart disease or stroke was 2.02 when comparing women with PCOS to women without PCOS; BMI adjustment did not affect this finding (102).

In summary, data from prospective end point trials about cardiovascular morbidity and mortality and from meta-analyses are scarce and controversial. Nevertheless, since the early phases of the atherosclerotic process have been well documented in PCOS women and are reversible before progressing to clinically important disease, it is reasonable to implement present knowledge of cardiovascular risk into clinical management of PCOS, especially regarding non-pharmacologic measures such as exercise and healthy lifestyle (103). At present, longitudinal screening for cardiometabolic risk factors in PCOS is recommended by guidelines of several international societies, including BMI, waist circumference, blood pressure, fasting lipid levels measurement and screening for impaired glucose tolerance and type 2 diabetes mellitus (103, 104, 105, 106). Assessment for cigarette smoking, 
OSA, depression and anxiety is also advised, with further management of those if needed.

\section{Possible therapeutic interventions in PCOS with beneficial effects on cardiovascular and metabolic risk factors}

Since PCOS is a complex polygenic disorder with important environmental influences, especially those that contribute to obesity (2), it should be stressed that there is a relative lack of systematic prospective studies investigating long-term effects of different lifestyle interventions in comparison to studies investigating pharmacological interventions.

Moreover, given the high prevalence of the syndrome, public media coverage, which was very efficient in educating the public about other diseases and health issues, such as diabetes, aids, smoking etc., is still insufficient in the case of PCOS. Several studies were published exploring the influence of public media coverage of other health issues $(107,108,109)$. However, the only study exploring how digital (online) teen and women's magazines portray women with PCOS found that articles depicted PCOS symptoms only as a hindrance to women's social roles as wives and mothers and largely placed personal responsibility on women to improve their health (110). Moreover, experiences of Latin and African American women and adolescents with PCOS were absent from these articles. A systematic approach coordinated by international endocrine organizations would be prudent for adequate management of this large group of patients.

\section{Diet}

Positive effects of even 5-10\% weight loss on reducing risk factors for cardiovascular disease, type 2 diabetes, endocrine and reproductive parameters in PCOS have been reported (111). A study investigating the effects of a high-protein, low-glycemic-load diet compared with a conventional hypocaloric diet on reproductive hormones, inflammatory markers, lipids, glucose and insulin levels in obese women with PCOS showed that both hypocaloric diets significantly reduced body weight and androgens. However, the combination of high-protein and low-glycemic-load foods in a modified diet caused a significant increase in insulin sensitivity and a decrease in high-sensitivity CRP (hsCRP) level when compared with a conventional diet (112). Another study in overweight and obese PCOS subjects investigated a Mediterranean-inspired low-glycemic-load anti-inflammatory diet (based on combinations of nutrients; encouraging the consumption of legumes, fish and low-fat dairy products) and regular exercise (all participants were instructed to use the stairs to the upper floor up and down for $30 \mathrm{~min} /$ day, and three times $10 \mathrm{~min} /$ day of sit-ups or abdominal crunches) + five cups of green tea intake daily. After 12 weeks, they found moderate weight loss $(6.3 \mathrm{~kg}$ or $7.2 \%)$ and significant improvements in body composition, hormones and menstrual cyclicity, blood pressure, glucose homeostasis, dyslipidemia, CRP and serum amyloid A (surrogate measures of cardiovascular risk) (113).

Vitamin D deficiency is reported to be common in PCOS (114). It may exacerbate symptoms of PCOS, with observational studies showing lower 25-OH-vitamin D levels to be associated with insulin resistance, ovulatory and menstrual irregularities, lower pregnancy success, hirsutism, hyperandrogenism, obesity and elevated cardiovascular disease risk factors. In a small interventional study, vitamin D therapy in PCOS patients was shown to have beneficial effect on some cardiovascular risk factors (decreased serum total cholesterol, triglycerides and very low-density lipoprotein (VLDL) but it did not affect serum HDL cholesterol, LDL cholesterol, apolipoprotein A1 and hsCRP concentrations (115). A recent meta-analysis found that lower serum vitamin D levels were related to metabolic and hormonal disorders in women with PCOS such as increased levels of fasting glucose and HOMA-IR compared to those without vitamin D deficiency (116). This meta-analysis found no evidence that vitamin D supplementation reduced metabolic and hormonal dysregulations in PCOS. Another systematic review also reported possible inverse association between vitamin $\mathrm{D}$ status and metabolic disturbances in PCOS but due to the heterogeneity of the studies omitted from drawing definite conclusions (117). Regarding possible beneficial effects of vitamin D supplementation on cardiovascular risk factors, we should acknowledge that current evidence is limited and further prospective randomized clinical trials are required.

\section{Exercise/lifestyle modification}

Supervised exercise (16 weeks) in women with PCOS improves endothelial function, an adaptation associated with reduced cardiovascular risk. This change occurs independently of changes in body weight or composition, which further stresses the fact that success of public health interventions in PCOS should not be solely judged by weight loss (118). A systematic review of the impact of http://www.endocrineconnections.org https://doi.org/10.1530/EC-18-0129
(C) 2018 The authors Published by Bioscientifica Ltd
This work is licensed under a Creative Commons Attribution-NonCommercial 4.0 International License. 
lifestyle modification interventions on outcomes of women with PCOS suggests that lifestyle modification reduces fasting blood glucose and insulin levels in women with PCOS with metformin having similar effects. Translation of these short-term effects to patient-important outcomes, beyond diabetes prevention, remains uncertain (119).

On the other hand, it was shown that exercise training (20 weeks) provided no additional benefit to following a high-protein, hypocaloric diet on markers of endothelial function in overweight/obese women with PCOS (120). In a small study, 40-min bout of aerobic exercise was reported to induce differential expression of insulin resistancerelated genes in skeletal muscles of PCOS patients (121). It should be emphasized that all interventions in above studies were of relatively short duration. Further research should elucidate long-term effects of such interventions.

\section{Medical treatment}

Metformin has been used as a treatment option for PCOS for two decades (122). Metformin increases insulin sensitivity by decreasing gluconeogenesis, lipogenesis and enhancing glucose uptake in the liver, skeletal muscle, adipose tissue and ovaries (123). It was shown to have beneficial effects on cardiovascular risk factors in PCOS $(124,125)$. In PCOS, it can be used as a single treatment or as part of a combination treatment. It was shown that variations in treatment response to metformin relate to differences in baseline BMI and testosterone levels in different PCOS patients (126). A recent meta-analysis investigating effects of metformin in PCOS that included 14 randomized clinical trials reported that treatment with metformin reduced BMI, waist-to-hip ratio, had a significant beneficial effect on systolic and diastolic blood pressure and triglyceride levels (but not on total, LDL and HDL cholesterol). In comparison to placebo, it did not significantly affect fasting blood glucose levels, HOMA-IR or fasting insulin. However, it significantly affected glucose insulin ratio (127).

Another meta-analysis showed that combination of lifestyle intervention (defined as any duration of diet, behavioral change, exercise) plus metformin for 6 months is associated with lower BMI and subcutaneous adipose tissue as compared to lifestyle plus placebo (128).

A study investigating oral contraception (ethinyl estradiol plus cyproterone acetate) effects vs combination of low-dose pioglitazone plus flutamide plus metformin for 18 months in non-obese adolescent girls with androgen excess found that both regimes attenuated androgen excess. However, during and 6 months after treatment,

$$
\text { http://www.endocrineconnections.org }
$$

the group treated with pioglitazone/flutamide/metformin had a lower glucose-induced insulinemia, lower CRP levels and thinner carotid intima-media thickness. Moreover, they had less visceral adipose tissue, had a higher lean mass. Six months after the treatment, they were more likely to have regular cycles in comparison to the group treated with oral contraception (129). Authors of the study emphasized that reducing androgen excess in adolescence influences the posttreatment phenotype so the type of intervention chosen in adolescence holds the potential to prevent part of the androgen excess phenotype in adulthood including adiposity, subfertility and cardiovascular risk.

Glucagon-like peptide- 1 receptor agonists that are used to treat type 2 diabetes and obesity have been explored in PCOS and have shown a beneficial effect on weight loss (130). However, they also have beneficial effects on cardiovascular system $(131,132)$. The possible beneficial effects of liraglutide treatment in PCOS on cardiovascular system have been explored in a rat model of PCOS treated for 4 weeks and showed improved glucose excursion during oral glucose tolerance test and lower blood pressure (rats were hypertensive before treatment) (133).

Another study showed that both metformin and exenatide treatments for 24 weeks were associated with weight loss; however, combination treatment had an additive effect (134). In this study, all subjects were insulin resistant at baseline - a greater improvement of HOMA-IR with combination therapy was found. However, there was a lack of statistically significant differences between two mono-treatment modalities.

A study investigating metformin-treated women with PCOS with persistent insulin resistance showed that add-on dipeptidyl dipeptidase- 4 inhibitor alogliptin alone or in combination with pioglitazone improved beta cell function and insulin sensitivity (135).

Also oral spironolactone, an androgen receptor and mineralocorticoid receptor antagonist, is used in PCOS to reduce the growth of terminal hair (2). Our group was the first to report that spironolactone treatment improved endothelial dysfunction in non-obese, non-insulinresistant PCOS patients (136).

Combined oral contraceptives are frequently used in PCOS due to their effectiveness in regulating menses (also reducing risk of endometrial hyperplasia) and reducing hirsutism (2). Concern has been raised that they could contribute to increased cardiovascular risk in PCOS by increasing blood pressure and triglyceride levels (106).

Furthermore, in PCOS, bariatric surgery can be effective in achieving significant weight loss, restoration

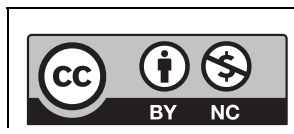

This work is licensed under a Creative Commons Attribution-NonCommercial 4.0 International License. 
of the hypothalamic-pituitary-ovarian axis, reduction of cardiovascular risk and even in improving pregnancy outcomes (137). A recent meta-analysis indicated that surgically induced weight loss in women with severe obesity and PCOS resulted in marked decreases in serum levels of total and free testosterone and the resolution of hirsutism and menstrual dysfunction in as many as 53\% and $96 \%$ of the patients, respectively, leading to a striking PCOS resolution rate of 96\% (95\% CI, 88-100\%); however, whether PCOS might reappear in the patients who regain weight is currently unknown (138). Therefore, bariatric surgery should be considered as part of the treatment in obese PCOS women, especially in those with metabolic syndrome.

\section{Conclusion}

The data are firm that women with PCOS represent a population with a high prevalence of metabolic disturbance and cardiovascular risk factors, with different PCOS phenotypes differing significantly in their risk that aggravates with severity of androgen excess. Therefore, besides treating the classical signs and symptoms of PCOS, management of these patients should also aim to improve metabolic and cardiovascular risk with lifestyle changes considered as a crucial part of treatment.

As data on cardiovascular morbidity and mortality in PCOS population of women are discordant, prospective long-term multicentric epidemiological studies, including women in early reproductive age and following them into late menopause when most cardiovascular events happen, are needed to clarify the controversial issues on morbidity and define the impact of hyperandrogenemia on cardiometabolic risk at different stages in life of PCOS women.

\section{Declaration of interest}

The authors declare that there is no conflict of interest that could be perceived as prejudicing the impartiality of this review.

\section{Funding}

This work did not receive any specific grant from any funding agency in the public, commercial or not-for-profit sector.

\section{References}

1 Dumesic DA, Oberfield SE, Stener-Victorin E, Marshall JC, Laven JS \& Legro RS. Scientific statement on the diagnostic criteria, epidemiology, pathophysiology, and molecular genetics of polycystic ovary syndrome. Endocrine Reviews 201536 487-525. (https://doi. org/10.1210/er.2015-1018)

2 McCartney CR \& Marshall JC. Polycystic ovary syndrome. New England Journal of Medicine 2016375 54-64. (https://doi.org/10.1056/ NEJMcp1514916)

3 Diamanti-Kandarakis E, Kouli CR, Bergiele AT, Filandra FA, Tsianateli TC, Spina GG, Zapanti ED \& Bartzis MI. A survey of the polycystic ovary syndrome in the Greek island of Lesbos: hormonal and metabolic profile. Journal of Clinical Endocrinology and Metabolism 199984 4006-4011. (https://doi.org/10.1210/jcem.84.11.6148)

4 Rotterdam ESHRE/ASRM-Sponsored PCOS Consensus Workshop Group. Revised 2003 consensus on diagnostic criteria and long-term health risks related to polycystic ovary syndrome (PCOS). Human Reproduction 200419 41-47.

5 Zawadski J \& Dunaif A. Diagnostic criteria for polycystic ovary syndrome: towards a rational approach. In Polycystic Ovary Syndrome, pp 377-384. Eds A Dunaif, HR Givens, FP Haseltine \& G Merriam. Boston, MA, USA: Blackwell Scientific, 1992.

6 Paterakis TS \& Diamanti-Kandarakis E. Aspects of cardiometabolic risk in women with polycystic ovary syndrome. Current Obesity Reports 20143 377-386. (https://doi.org/10.1007/s13679-014-0127-6)

7 Dunaif A, Segal KR, Shelley DR, Green G, Dobrjansky A \& Licholai T. Evidence for distinctive and intrinsic defects in insulin action in polycystic ovary syndrome. Diabetes 199241 1257-1266. (https:// doi.org/10.2337/diab.41.10.1257)

8 Azziz R, Carmina E, Chen Z, Dunaif A, Laven JS, Legro RS, Lizneva D, Natterson-Horowtiz B, Teede HJ \& Yildiz BO. Polycystic ovary syndrome. Nature Reviews Disease Primer 20162 16057. (https://doi. org/10.1038/nrdp.2016.57)

9 Ehrmann DA, Barnes RB, Rosenfield RL, Cavaghan MK \& Imperial J. Prevalence of impaired glucose tolerance and diabetes in women with polycystic ovary syndrome. Diabetes Care 199922 141-146. (https://doi.org/10.2337/diacare.22.1.141)

10 Legro RS, Kunselman AR, Dodson WC \& Dunaif A. Prevalence and predictors of risk for type 2 diabetes mellitus and impaired glucose tolerance in polycystic ovary syndrome: a prospective, controlled study in 254 affected women. Journal of Clinical Endocrinology and Metabolism 199984 165-169. (https://doi.org/10.1210/ jcem.84.1.5393)

11 Legro RS, Gnatuk CL, Kunselman AR \& Dunaif A. Changes in glucose tolerance over time in women with polycystic ovary syndrome: a controlled study. Journal of Clinical Endocrinology and Metabolism 2005 90 3236-3242. (https://doi.org/10.1210/jc.2004-1843)

12 Norman RJ, Masters L, Milner CR, Wang JX \& Davies MJ. Relative risk of conversion from normoglycaemia to impaired glucose tolerance or non-insulin dependent diabetes mellitus in polycystic ovarian syndrome. Human Reproduction 200116 1995-1998. (https://doi. org/10.1093/humrep/16.9.1995)

13 Boudreaux MY, Talbott EO, Kip KE, Brooks MM \& Witchel SF. Risk of T2DM and impaired fasting glucose among PCOS subjects: results of an 8-year follow-up. Current Diabates Reports 20066 77-83. (https:// doi.org/10.1007/s11892-006-0056-1)

14 Livadas S, Kollias A, Panidis D \& Diamanti-Kandarakis E. Diverse impacts of aging on insulin resistance in lean and obese women with polycystic ovary syndrome: evidence from 1345 women with the syndrome. European Journal of Endocrinology 2014171 301-309. (https://doi.org/10.1530/EJE-13-1007)

15 Moghetti P, Tosi F, Bonin C, Di Sarra D, Fiers T, Kaufman JM, Giagulli VA, Signori C, Zambotti F, Dall'Alda M, et al. Divergences in insulin resistance between the different phenotypes of the polycystic ovary syndrome. Journal of Clinical Endocrinology and Metabolism 2013 98 E628-37. (https://doi.org/10.1210/jc.2012-3908)

16 Bil E, Dilbaz B, Cirik DA, Ozelci R, Ozkaya E \& Dilbaz S. Metabolic syndrome and metabolic risk profile according to polycystic ovary syndrome phenotype. Journal of Obstetrics and Gynaecology Research 201642 837-843. (https://doi.org/10.1111/jog.12985) http://www.endocrineconnections.org https://doi.org/10.1530/EC-18-0129 (c) 2018 The authors Published by Bioscientifica Ltd
This work is licensed under a Creative Commons Attribution-NonCommercial 4.0 International License. 
17 Laakso M \& Kuusisto J. Insulin resistance and hyperglycaemia in cardiovascular disease development. Nature Reviews Endocrinology 201410 293-302. (https://doi.org/10.1038/nrendo.2014.29)

18 Alberti KG, Eckel RH, Grundy SM, Zimmet PZ, Cleeman JI, Donato KA, Fruchart JC, James WP, Loria CM, Smith SC Jr, et al. Harmonizing the metabolic syndrome: a joint interim statement of the International Diabetes Federation Task Force on Epidemiology and Prevention; National Heart, Lung, and Blood Institute; American Heart Association; World Heart Federation; International Atherosclerosis Society; and International Association for the Study of Obesity. Circulation 2009120 1640-1645. (https://doi. org/10.1161/CIRCULATIONAHA.109.192644)

19 Ehrmann DA, Liljenquist DR, Kasza K, Azziz R, Legro RS, Ghazzi MN $\&$ PCOS/Troglitazone Study Group. Prevalence and predictors of the metabolic syndrome in women with polycystic ovary syndrome. Journal of Clinical Endocrinology and Metabolism 20069 48-53. (https://doi.org/10.1210/jc.2005-1329)

20 Apridonidze T, Essah PA, Iuorno MJ \& Nestler JE. Prevalence an characteristics of the metabolic syndrome in women with polycystic ovary syndrome. Journal of Clinical Endocrinology and Metabolism 2005 90 1929-1935. (https://doi.org/10.1210/jc.2004-1045)

21 Dokras A, Bochner M, Hollinrake E, Markham S, Vanvoorhis B \& Jagasia DH. Screening women with polycystic ovary syndrome for metabolic syndrome. Obstetrics and Gynecology 2005106 131-137. (https://doi.org/10.1097/01.AOG.0000167408.30893.6b)

22 Álvarez-Blasco F, Botella-Carretero JI, San Millán JL \& EscobarMorreale HF. Prevalence and characteristics of the polycystic ovary syndrome in overweight and obese women. Archives of Internal Medicine 2006166 2081. (https://doi.org/10.1001/ archinte.166.19.2081)

23 Carmina E, Napoli N, Longo RA, Rini GB \& Lobo RA. Metabolic syndrome in polycystic ovary syndrome (PCOS): lower prevalence in southern Italy than in the USA and the influence of criteria for the diagnosis of PCOS. European Journal of Endocrinology $2006 \mathbf{1 5 4}$ 141-145. (https://doi.org/10.1530/eje.1.02058)

24 Moran LJ, Misso ML, Wild RA \& Norman RJ. Impaired glucose tolerance, type 2 diabetes and metabolic syndrome in polycystic ovary syndrome: a systematic review and meta-analysis. Human Reproduction Update 201016 347-363. (https://doi.org/10.1093/ humupd/dmq001)

25 Yildiz BO, Knochenhauer ES \& Azziz R. Impact of obesity on the risk for polycystic ovary syndrome. Journal of Clinical Endocrinology and Metabolism 200893 162-168. (https://doi.org/10.1210/jc.2007-1834)

26 Carmina E, Legro RS, Stamets K, Lowell J \& Lobo RA. Difference in body weight between American and Italian women with polycystic ovary syndrome: influence of the diet. Human Reproduction $2003 \mathbf{1 8}$ 2289-2293. (https://doi.org/10.1093/humrep/deg440)

27 Godoy-Matos AF, Vaisman F, Pedrosa AP, Farias MLF, Mendonça LMC \& Pinheiro MFMC. Central-to-peripheral fat ratio, but not peripheral body fat, is related to insulin resistance and androgen markers in polycystic ovary syndrome. Gynecological Endocrinology 200925 793-798. (https://doi.org/10.3109/09513590903015528)

28 Strowitzki T, Halser B \& Demant T. Body fat distribution, insulin sensitivity, ovarian dysfunction and serum lipoproteins in patients with polycystic ovary syndrome. Gynecological Endocrinology 200216 45-51. (https://doi.org/10.1080/gye.16.1.45.51)

29 Cosar E, Üçok K, Akgün L, Koken G, Sahin FK, Arioz DT \& Baş O. Body fat composition and distribution in women with polycystic ovary syndrome. Gynecological Endocrinology 200824 428-432. (https://doi.org/10.1080/09513590802234253)

30 Liou T-H, Yang J-H, Hsieh C-H, Lee C-Y, Hsu C-S \& Hsu M-I. Clinical and biochemical presentations of polycystic ovary syndrome among obese and nonobese women. Fertility and Sterility 200992 1960-1965. (https://doi.org/10.1016/j.fertnstert.2008.09.003)

31 Kiddy DS, Sharp PS, White DM, Scanlon MF, Mason HD, Bray CS, Polson DW, Reed MJ \& Franks S. Differences in clinical and endocrine features between obese and non-obese subjects with polycystic ovary syndrome: an analysis of 263 consecutive cases. Clinical Endocrinology 199032 213-220. (https://doi. org/10.1111/j.1365-2265.1990.tb00857.x)

32 Karabulut A, Yaylali GF, Demirlenk S, Sevket O \& Acun A. Evaluation of body fat distribution in PCOS and its association with carotid atherosclerosis and insulin resistance. Gynecological Endocrinology 201228 111-114. (https://doi.org/10.3109/09513590.2011.589929)

33 Conway GS, Agrawal R, Betteridge DJ \& Jacobs HS. Risk factors for coronary artery disease in lean and obese women with the polycystic ovary syndrome. Clinical Endocrinology 199237 119-125. (https:// doi.org/10.1111/j.1365-2265.1992.tb02295.x)

34 Legro RS, Kunselman AR \& Dunaif A. Prevalence and predictors of dyslipidemia in women with polycystic ovary syndrome. American Journal of Medicine 2001111 607-613. (https://doi.org/10.1016/ S0002-9343(01)00948-2)

35 Lim SS, Norman RJ, Davies MJ \& Moran LJ. The effect of obesity on polycystic ovary syndrome: a systematic review and meta-analysis. Obesity Reviews 201314 95-109. (https://doi.org/10.1111/j.1467789X.2012.01053.x)

36 Svendsen PF, Nilas L, Norgaard K, Jensen J-EB \& Madsbad S. Obesity, body composition and metabolic disturbances in polycystic ovary syndrome. Human Reproduction 200823 2113-2121. (https://doi. org/10.1093/humrep/den211)

37 Cree-Green, Melanie, Rahat, Haseeb, Newcomer, B \& Bergman B. Insulin resistance, hyperinsulinemia and mitochondria dysfunction in non-obese girls woth polycystic ovary syndrome. Journal of the Endocrine Society 2017 1931-944. (https://doi.org/10.1210/js.201700192)

38 Thaler MA, Seifert-Klauss V \& Luppa PB. The biomarker sex hormone-binding globulin - from established applications to emerging trends in clinical medicine. Best Practice and Research: Clinical Endocrinology and Metabolism 201529 749-760. (https://doi. org/10.1016/j.beem.2015.06.005)

39 Sutton-Tyrrell K, Wildman RP, Matthews KA, Chae C, Lasley BL, Brockwell S, Pasternak RC, Lloyd-Jones D, Sowers MF, Torréns JI, et al. Sex hormone-binding globulin and the free androgen index are related to cardiovascular risk factors in multiethnic premenopausal and perimenopausal women enrolled in the Study of Women Across the Nation (SWAN). Circulation. 2005111 1242-1249. (https://doi. org/10.1161/01.CIR.0000157697.54255.CE)

40 Helvaci N, Karabulut E, Demir AU \& Yildiz BO. Polycystic ovary syndrome and the risk of obstructive sleep apnea: a meta-analysis and review of the literature. Endocrine Connections 20176 437-445. (https://doi.org/10.1530/EC-17-0129)

41 Fernandez RC, Moore VM, Van Ryswyk EM, Varcoe TJ, Rodgers RJ March WA, Moran LJ, Avery JC, McEvoy RD \& Davies MJ. Sleep disturbances in women with polycystic ovary syndrome: prevalence, pathophysiology, impact and management strategies. Nature and Science of Sleep 201810 45-64. (https://doi.org/10.2147/NSS.S127475)

42 Caples SM, Gami AS \& Somers VK. Obstructive sleep apnea. Annals of Internal Medicine 2005142 187-197. (https://doi.org/10.7326/00034819-142-3-200502010-00010)

43 Peppard PE, Young T, Palta M \& Skatrud J. Prospective study of the association between sleep-disordered breathing and hypertension. New England Journal of Medicine 2000342 1378-1384. (https://doi. org/10.1056/NEJM200005113421901)

44 Peker Y, Carlson J \& Hedner J. Increased incidence of coronary artery disease in sleep apnoea: a long-term follow-up. European Respiratory Journal 200628 596-602. (https://doi.org/10.1183/09031936.06.0010 7805)

45 Punjabi NM \& Polotsky VY. Disorders of glucose metabolism in sleep apnea. Journal of Applied Physiology 200599 1998-2007. (https://doi. org/10.1152/japplphysiol.00695.2005)

46 Tasali E, Chapotot F, Leproult R, Whitmore H \& Ehrmann DA. Treatment of obstructive sleep apnea improves cardiometabolic http://www.endocrineconnections.org

https://doi.org/10.1530/EC-18-0129
() 2018 The authors

Published by Bioscientifica Ltd
This work is licensed under a Creative Commons Attribution-NonCommercial 4.0 International License. 
function in young obese women with polycystic ovary syndrome. Journal of Clinical Endocrinology and Metabolism 201196 365-374. (https://doi.org/10.1210/jc.2010-1187)

47 Sun Y, Huang Z-Y, Sun Q-R, Qiu L-P, Zhou T-T \& Zhou G-H. CPAP therapy reduces blood pressure for patients with obstructive sleep apnoea: an update meta-analysis of randomized clinical trials. Acta Cardiologica 201671 275-280. (https://doi.org/10.1080/ AC.71.3.3152087)

48 Schwarz EI, Puhan MA, Schlatzer C, Stradling JR \& Kohler M. Effect of CPAP therapy on endothelial function in obstructive sleep apnoea: a systematic review and meta-analysis. Respirology 201520 889-895. (https://doi.org/10.1111/resp.12573)

49 Xu H, Wang Y, Guan J, Yi H \& Yin S. Effect of CPAP on endothelial function in subjects with obstructive sleep apnea: a meta-analysis. Respiratory Care 201560 749-755. (https://doi.org/10.4187/ respcare.03739)

50 Chen L, Kuang J, Pei J-H, Chen HM, Chen Z, Li ZW, Yang HZ, Fu XY, Wang L, Chen ZJ, et al. Continuous positive airway pressure and diabetes risk in sleep apnea patients: a systemic review and metaanalysis. European Journal of Internal Medicine 201739 39-50. (https:// doi.org/10.1016/j.ejim.2016.11.010)

51 Papadakis G, Kandaraki E, Papalou O, Vryonidou A \& DiamantiKandarakis E. Is cardiovascular risk in women with PCOS a real risk? Current insights. Minerva Endocrinologica 201742 340-355. (https:// doi.org/10.23736/S0391-1977.17.02609-8)

52 Sales M, Sóter M, Candido A, Fernandes AP, Oliveira FR, Ferreira AC, Sousa MO, Ferreira CN \& Gomes KB. Correlation between plasminogen activator inhibitor-1 (PAI-1) promoter 4G/5G polymorphism and metabolic/proinflammatory factors in polycystic ovary syndrome. Gynecological Endocrinology 201329 936-939. (https://doi.org/10.3109/09513590.2013.819086)

53 Güldaş M, Altinkaya SÖ, Nergiz S, Demircan-Sezer S \& Yüksel H. Elevated thrombin activatable fibrinolysis inhibitor levels in women with polycystic ovary syndrome. Gynecological Endocrinology 201531 536-539. (https://doi.org/10.3109/09513590.2015.1018161)

54 Victor VM, Rovira-Llopis S, Bañuls C, Diaz-Morales N, Martinez de Maranon A, Rios-Navarro C, Alvarez A, Gomez M, Rocha M \& Hernández-Mijares A. Insulin resistance in PCOS patients enhances oxidative stress and leukocyte adhesion: role of myeloperoxidase. PLOS ONE 201611 e0151960. (https://doi.org/10.1371/journal. pone.0151960)

55 Kumarendran B, O’Reilly MW, Manolopoulos KN, Toulis KA, Gokhale KM, Sitch AJ, Wijeyaratne CN, Coomarasamy A, Arlt W \& Nirantharakumar K. Polycystic ovary syndrome, androgen excess, and the risk of nonalcoholic fatty liver disease in women: a longitudinal study based on a United Kingdom primary care database. PLoS Medicine 201815 e1002542. (https://doi.org/10.1371/ journal.pmed.1002542)

56 Armstrong MJ, Adams LA, Canbay A \& Syn W-K. Extrahepatic complications of nonalcoholic fatty liver disease. Hepatology 201459 1174-1197. (https://doi.org/10.1002/hep.26717)

57 Ramezani-Binabaj M, Motalebi M, Karimi-Sari H, Rezaee-Zavareh MS $\&$ Alavian SM. Are women with polycystic ovarian syndrome at a high risk of non-alcoholic Fatty liver disease; a meta-analysis. Hepatitis Monthly 201414 e23235. (https://doi.org/10.5812/ hepatmon.23235)

58 Vassilatou E, Vassiliadi DA, Salambasis K, Lazaridou H, Koutsomitopoulos N, Kelekis N, Kassanos D, Hadjidakis D \& Dimitriadis G. Increased prevalence of polycystic ovary syndrome in premenopausal women with nonalcoholic fatty liver disease. European Journal of Endocrinology 2015173 739-747. (https://doi. org/10.1530/EJE-15-0567)

59 Romanowski MD, Parolin MB, Freitas ACT, Piazza MJ, Basso J \& Urbanetz AA. Prevalence of non-alcoholic fatty liver disease in women with polycystic ovary syndrome and its correlation with metabolic syndrome. Arquivos de Gastroenterologia 201552 117-123. (https://doi.org/10.1590/S0004-28032015000200008)

60 Diamanti-Kandarakis E, Katsikis I, Piperi C, Kandaraki E, Piouka A, Papavassiliou AG \& Panidis D. Increased serum advanced glycation end-products is a distinct finding in lean women with polycystic ovary syndrome (PCOS). Clinical Endocrinology 200869 634-641. (https://doi.org/10.1111/j.1365-2265.2008.03247.x)

61 Pertynska-Marczewska M, Diamanti-Kandarakis E, Zhang J \& Merhi Z. Advanced glycation end products: a link between metabolic and endothelial dysfunction in polycystic ovary syndrome? Metabolism 201564 1564-1573. (https://doi.org/10.1016/j. metabol.2015.08.010)

62 Toulis KA, Goulis DG, Mintziori G, Kintiraki E, Eukarpidis E, Mouratoglou SA, Pavlaki A, Stergianos S, Poulasouchidou M, Tzellos TG, et al. Meta-analysis of cardiovascular disease risk markers in women with polycystic ovary syndrome. Human Reproduction Update 201117 741-760. (https://doi.org/10.1093/humupd/dmr025)

63 Barber TM, Vojtechova P \& Franks S. The impact of hyperandrogenism in female obesity and cardiometabolic diseases associated with polycystic ovary syndrome. Hormone Molecular Biology and Clinical Investigation 201315 91-103. (https://doi. org/10.1515/hmbci-2013-0014)

64 Ehrmann DA, Liljenquist DR, Kasza K, Azziz R, Legro RS, Ghazzi MN $\&$ PCOS/Troglitazone Study Group. Prevalence and predictors of the metabolic syndrome in women with polycystic ovary syndrome. Journal of Clinical Endocrinology and Metabolism 200691 48-53. (https://doi.org/10.1210/jc.2005-1329)

65 Abbott DH, Dumesic DA \& Franks S. Developmental origin of polycystic ovary syndrome - a hypothesis. Journal of Endocrinology 2002174 1-5. (https://doi.org/10.1677/joe.0.1740001)

66 Elbers JMH, Asscheman H, Seidell JC, Megens JAJ \& Gooren LJG. Long-term testosterone administration increases visceral fat in female to male transsexuals. Journal of Clinical Endocrinology and Metabolism 199782 2044-2047. (https://doi.org/10.1210/ jcem.82.7.4078)

67 Jones H, Sprung VS, Pugh CJA, Daousi C, Irwin A, Aziz N, Adams VL, Thomas EL, Bell JD, Kemp GJ, et al. Polycystic ovary syndrome with hyperandrogenism is characterized by an increased risk of hepatic steatosis compared to nonhyperandrogenic PCOS phenotypes and healthy controls, independent of obesity and insulin resistance. Journal of Clinical Endocrinology and Metabolism 201297 3709-3716. (https://doi.org/10.1210/jc.2012-1382)

68 Barber TM, Wass JAH, McCarthy MI \& Franks S. Metabolic characteristics of women with polycystic ovaries and oligoamenorrhoea but normal androgen levels: implications for the management of polycystic ovary syndrome. Clinical Endocrinology 200766 513-517. (https://doi.org/10.1111/j.13652265.2007.02764.x)

69 Broekmans F, Knauff E, Valkenburg O, Laven J, Eijkemans M \& Fauser B. PCOS according to the Rotterdam consensus criteria: change in prevalence among WHO-II anovulation and association with metabolic factors. BJOG 2006113 1210-1217. (https://doi. org/10.1111/j.1471-0528.2006.01008.x)

70 O'Reilly MW, Taylor AE, Crabtree NJ, Hughes BA, Capper F, Crowley RK, Stewart PM, Tomlinson JW \& Arlt W. Hyperandrogenemia predicts metabolic phenotype in polycystic ovary syndrome: the utility of serum androstenedione. Journal of Clinical Endocrinology and Metabolism 201499 1027-1036. (https:// doi.org/10.1210/jc.2013-3399)

71 Meun C, Franco OH, Dhana K, Jaspers L, Muka T, Louwers Y, Ikram MA, Fauser BCJM, Kavousi M \& Laven JSE. High androgens in postmenopausal women and the risk for atherosclerosis and cardiovascular disease: the Rotterdam Study. Journal of Clinical Endocrinology and Metabolism 2018103 1622-1630. (https://doi. org/10.1210/jc.2017-02421) http://www.endocrineconnections.org https://doi.org/10.1530/EC-18-0129

(C) 2018 The authors Published by Bioscientifica Ltd

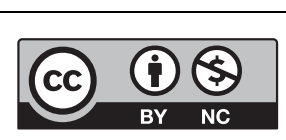

This work is licensed under a Creative Commons Attribution-NonCommercial 4.0 International License. 
72 Ganie M, Zargar M, Zargar MA, Bhat D, Mir MM, Jan A, Shah ZA, Jan V, Rasool R \& Naqati A. Prevalence of metabolic syndrome in the family members of women with polycystic ovary syndrome from North India. Indian Journal of Endocrinology and Metabolism 201418 364. (https://doi.org/10.4103/2230-8210.131186)

73 Sáez ME, González-Sánchez JL, Ramírez-Lorca R, Martínez-Larrad MT, Zabena C, González A, Morón FJ, Ruiz A \& Serrano-Ríos M. The CAPN10 gene is associated with insulin resistance phenotypes in the spanish population. PLoS ONE 20083 e2953. (https://doi. org/10.1371/journal.pone.0002953)

74 Baldani D, Skrgatic L, Cerne J, Oguic S, Gersak B \& Gersak K. Association between serum levels and pentanucleotide polymorphism in the sex hormone binding globulin gene and cardiovascular risk factors in females with polycystic ovary syndrome. Molecular Medicine Reports 201411 3941-3947. (https:// doi.org/10.3892/mmr.2014.3117)

75 Zhang R, Song Q, Liu H, Bai H, Zhang Y, Liu Q, Guan L \& Fan P. Effect of the R92H and A379V genotypes of platelet-activating factor acetylhydrolase on its enzyme activity, oxidative stress and metabolic profile in Chinese women with polycystic ovary syndrome. Lipids in Health and Disease 201716 57. (https://doi.org/10.1186/s12944-017. 0448-z)

76 Erdogan M, Karadeniz M, Berdeli A, Tamsel S \& Yilmaz C. The relationship of the interleukin-6 -174 G>C gene polymorphism with cardiovascular risk factors in Turkish polycystic ovary syndrome patients. International Journal of Immunogenetics 200936 283-288. (https://doi.org/10.1111/j.1744-313X.2009.00867.x)

77 Cetinkalp S, Karadeniz M, Erdogan M, Zengi A, Cetintas V, Tetik A Eroglu Z, Kosova B, Ozgen AG, Saygili F, et al. Apolipoprotein E gene polymorphism and polycystic ovary syndrome patients in Western Anatolia, Turkey. Journal of Assisted Reproduction and Genetics 200926 1-6. (https://doi.org/10.1007/s10815-008-9280-8)

78 Ozegowska K, Bogacz A, Bartkowiak-WIeczorek J, SeremakMrozikiewicz A \& Pawelczyk L. Is there association between the development of metabolic syndrome in polycystic ovary syndrome patients with the C677T metylenetetrahydrofolate reuctace gene polymorphism? Polish Gynaecology 201687 246-253. (https://doi. org/10.17772/gp/61751)

79 Jones MR, Chua AK, Mengesha EA, Taylor KD, Chen YD, Li X, Krauss RM, Rotter JI, Reproductive Medicine Network \& Legro RS. Metabolic and cardiovascular genes in polycystic ovary syndrome: a candidate-wide association study (CWAS). Steroids 201277 317-322. (https://doi.org/10.1016/j.steroids.2011.12.005)

80 Paradisi G, Steinberg HO, Hempfling A, Cronin J, Hook G, Shepard MK \& Baron AD. Polycystic ovary syndrome is associated with endothelial dysfunction. Circulation 2001103 1410-1415. (https://doi.org/10.1161/01.CIR.103.10.1410)

81 Kravariti M, Naka KK, Kalantaridou SN, Kazakos N, Katsouras CS, Makrigiannakis A, Paraskevaidis EA, Chrousos GP, Tsatsoulis A \& Michalis LK. Predictors of endothelial dysfunction in young women with polycystic ovary syndrome. Journal of Clinical Endocrinology and Metabolism 200590 5088-5095. (https://doi.org/10.1210/jc.20050151)

82 Talbott EO, Guzick DS, Sutton-Tyrrell K, McHugh-Pemu KP, Zborowski JV, Remsberg KE \& Kuller LH. Evidence for association between polycystic ovary syndrome and premature carotid atherosclerosis in middle-aged women. Arteriosclerosis, Thrombosis and Vascular Biology 200020 2414-2421. (https://doi.org/10.1161/01. ATV.20.11.2414)

83 Luque-Ramirez M, Mendieta-Azcona C, Alvarez-Blasco F \& EscobarMorreale HF. Androgen excess is associated with the increased carotid intima-media thickness observed in young women with polycystic ovary syndrome. Human Reproduction 200722 3197-3203. (https:// doi.org/10.1093/humrep/dem324)

84 Talbott EO, Zborowski J V, Rager JR, Boudreaux MY, Edmundowicz DA \& Guzick DS. Evidence for an association between metabolic cardiovascular syndrome and coronary and aortic calcification among women with polycystic ovary syndrome. Journal of Clinical Endocrinology and Metabolism 200489 5454-5461. (https:// doi.org/10.1210/jc.2003-032237)

85 Orio F, Palomba S, Cascella T, De Simone B, Di Biase S, Russo T, Labella D, Zullo F, Lombardi G \& Colao A. Early impairment of endothelial structure and function in young normal-weight women with polycystic ovary syndrome. Journal of Clinical Endocrinology and Metabolism 200489 4588-4593. (https://doi.org/10.1210/jc.2003031867)

86 Sprung VS, Atkinson G, Cuthbertson DJ, Pugh CJ, Aziz N, Green DJ, Cable NT \& Jones H. Endothelial function measured using flowmediated dilation in polycystic ovary syndrome: a meta-analysis of the observational studies. Clinical Endocrinology 201378 438-446. (https://doi.org/10.1111/j.1365-2265.2012.04490.x)

87 Meyer ML, Malek AM, Wild RA, Korytkowski MT \& Talbott EO Carotid artery intima-media thickness in polycystic ovary syndrome: a systematic review and meta-analysis. Human Reproduction Update 201218 112-126. (https://doi.org/10.1093/humupd/dmr046)

88 Hurliman A, Keller Brown J, Maille N, Mandala M, Casson P \& Osol G. Hyperandrogenism and insulin resistance, not changes in body weight, mediate the development of endothelial dysfunction in a female rat model of polycystic ovary syndrome (PCOS). Endocrinology 2015156 4071-4080. (https://doi.org/10.1210/ en.2015-1159)

89 Calderon-Margalit R, Siscovick D, Merkin SS, Wang E, Daviglus ML, Schreiner PJ, Sternfeld B, Williams OD, Lewis CE, Azziz R, et al. Prospective association of polycystic ovary syndrome with coronary artery calcification and carotid-intima-media thickness: the coronary artery risk development in young adults women's study. Arteriosclerosis, Thrombosis and Vascular Biology 201434 2688-2694. (https://doi.org/10.1161/ATVBAHA.114.304136)

90 Patel SS, Truong U, King M, Ferland A, Moreau KL, Dorosz J, Hokanson JE, Wang H, Kinney GL, Maahs DM, et al. Obese adolescents with polycystic ovarian syndrome have elevated cardiovascular disease risk markers. Vascular Medicine 201722 85-95. (https://doi.org/10.1177/1358863X16682107)

91 Tripathy P, Sahu A, Sahu M \& Nagy A. Ultrasonographic evaluation of intra-abdominal fat distribution and study of its influence on subclinical atherosclerosis in women with polycystic ovarian syndrome. European Journal of Obstetrics, Gynecology and Reproductive Biology 2017217 18-22. (https://doi.org/10.1016/j. ejogrb.2017.08.011)

92 Ketel IJ, Stehouwer CD, Henry RM, Serne EH, Hompes P, Homburg R, Smulders YM \& Lambalk CB.Greater arterial stiffness in polycystic ovary syndrome (PCOS) is an obesity - but not a PCOS-associated phenomenon. Journal of Clinical Endocrinology and Metabolism 2010 95 4566-4575. (https://doi.org/10.1210/jc.2010-0868)

93 Macut D, Bačević M, Božić-Antić I, Bjekić-Macut J, Čivčić M, Erceg S, Vojnović Milutinović D, Stanojlović O, Andrić Z, KastratovićKotlica B, et al. Predictors of subclinical cardiovascular disease in women with polycystic ovary syndrome: interrelationship of dyslipidemia and arterial blood pressure. International Journal of Endocrinology 20152015 1-9. (https://doi. org/10.1155/2015/812610)

94 Glintborg D, Rubin KH, Nybo M, Abrahamsen B \& Andersen M. Cardiovascular disease in a nationwide population of Danish women with polycystic ovary syndrome. Cardiovascular Diabetology 201817 37. (https://doi.org/10.1186/s12933-018-0680-5)

95 Birdsall MA, Farquhar CM \& White HD. Association between polycystic ovaries and extent of coronary artery disease in women having cardiac catheterization. Annals of Internal Medicine 1997126 32-35. (https://doi.org/10.7326/0003-4819-126-1-199701010-00005) 96 Christian RC, Dumesic DA, Behrenbeck T, Oberg AL, Sheedy PF $\&$ Fitzpatrick LA. Prevalence and predictors of coronary artery calcification in women with polycystic ovary syndrome. Journal of

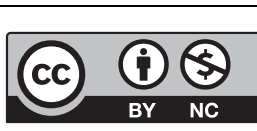

This work is licensed under a Creative Commons Attribution-NonCommercial 4.0 International License. 
Clinical Endocrinology and Metabolism 200388 2562-2568. (https:// doi.org/10.1210/jc.2003-030334)

97 Solomon CG, Hu FB, Dunaif A, Rich-Edwards JE, Stampfer MJ, Willett WC, Speizer FE \& Manson JE. Menstrual cycle irregularity and risk for future cardiovascular disease. Journal of Clinical Endocrinology and Metabolism 200287 2013-2017. (https://doi.org/10.1210/ jcem.87.5.8471)

98 Wild S, Pierpoint T, Jacobs H \& McKeigue P. Long-term consequences of polycystic ovary syndrome: results of a 31 year follow-up study. Human Fertility 20003 101-105. (https://doi.org/10.1080/146472700 2000198781)

99 Wang ET, Cirillo PM, Vittinghoff E, Bibbins-Domingo K, Cohn BA \& Cedars MI. Menstrual irregularity and cardiovascular mortality. Journal of Clinical Endocrinology and Metabolism 201196 E114-E118. (https://doi.org/10.1210/jc.2010-1709)

100 Ding T, Hardiman PJ, Petersen I, Wang F-F, Qu F \& Baio G. The prevalence of polycystic ovary syndrome in reproductive aged women of different ethnicity: a systematic review and metaanalysis. Oncotarget 20158 96351-96358. (https://doi.org/10.18632/ oncotarget.19180)

101 Schmidt J, Landin-Wilhelmsen K, Brännström M \& Dahlgren E. Cardiovascular disease and risk factors in PCOS women of postmenopausal age: a 21-year controlled follow-up study. Journal of Clinical Endocrinology and Metabolism 201196 3794-3803. (https:// doi.org/10.1210/jc.2011-1677)

102 de Groot PCM, Dekkers OM, Romijn JA, Dieben SWM \& Helmerhorst FM. PCOS, coronary heart disease, stroke and the influence of obesity: a systematic review and meta-analysis. Human Reproduction Update 201117 495-500. (https://doi.org/10.1093/ humupd/dmr001)

103 Wild RA, Carmina E, Diamanti-Kandarakis E, Dokras A, EscobarMorreale HF, Futterweit W, Lobo R, Norman RJ, Talbott E \& Dumesic DA. Assessment of cardiovascular risk and prevention of cardiovascular disease in women with the polycystic ovary syndrome: a consensus statement by the Androgen Excess and Polycystic Ovary Syndrome (AE-PCOS) Society. Journal of Clinical Endocrinology and Metabolism 201095 2038-2049. (https://doi.org/10.1210/jc.2009-2724)

104 Fauser BCJM, Tarlatzis BC, Rebar RW, Legro RS, Balen AH, Lobo R, Carmina E, Chang J, Yildiz BO, Laven JS, et al. Consensus on women's health aspects of polycystic ovary syndrome (PCOS): the Amsterdam ESHRE/ASRM-Sponsored 3rd PCOS Consensus Workshop Group. Fertility and Sterility 201297 28-38. (https://doi. org/10.1016/j.fertnstert.2011.09.024)

105 Conway G, Dewailly D, Diamanti-Kandarakis E, Escobar-Morreale HF, Franks S, Gambineri A, Kelestimur F, Macut D, Micic D, Pasquali R, et al. The polycystic ovary syndrome: a position statement from the European Society of Endocrinology. European Journal of Endocrinology 2014171 P1-P29. (https://doi.org/10.1530/EJE-14-0253)

106 Legro RS, Arslanian SA, Ehrmann DA, Hoeger KM, Murad MH Pasquali R, Welt CK \& Endocrine Society. Diagnosis and treatment of polycystic ovary syndrome: an Endocrine Society clinical practice guideline. Journal of Clinical Endocrinology and Metabolism 201398 4565-4592. (https://doi.org/10.1210/jc.2013-2350)

107 Pullman D, Zarzeczny A \& Picard A. Media, politics and science policy: MS and evidence from the CCSVI Trenches. BMC Medical Ethics 201314 6. (https://doi.org/10.1186/1472-6939-14-6)

108 Fishman PA. Impact of broadened coverage of smoking cessation treatments on cardiovascular disease. Current Cardiovascular Risk Reports 20126 542-548. (https://doi.org/10.1007/s12170-012-0275-8)

109 Barry CL, Martin A \& Busch SH. ADHD medication use following FDA risk warnings. Journal of Mental Health Policy and Economics 2012 15 119-125.

110 Sanchez N \& Jones H. 'Less than a wife': a study of polycystic ovary syndrome content in teen and women's digital magazines. Journal of Medical Internet Research 201618 e89. (https://doi.org/10.2196/ jmir.5417)
111 Moran LJ, Pasquali R, Teede HJ, Hoeger KM \& Norman RJ. Treatment of obesity in polycystic ovary syndrome: a position statement of the Androgen Excess and Polycystic Ovary Syndrome Society. Fertility and Sterility 200992 1966-1982. (https://doi.org/10.1016/j. fertnstert.2008.09.018)

112 Mehrabani HH, Salehpour S, Amiri Z, Farahani SJ, Meyer BJ \& Tahbaz F. Beneficial effects of a high-protein, low-glycemic-load hypocaloric diet in overweight and obese women with polycystic ovary syndrome: a randomized controlled intervention study. Journal of the American College of Nutrition 201231 117-125. (https://doi.org/ 10.1080/07315724.2012.10720017)

113 Salama A, Amine E, Salem HE \& Abd El Fattah N. Anti-inflammatory dietary combo in overweight and obese women with polycystic ovary syndrome. North American Journal of Medicine and Science 2015 7 310. (https://doi.org/10.4103/1947-2714.161246)

114 Thomson RL, Spedding S \& Buckley JD. Vitamin D in the aetiology and management of polycystic ovary syndrome. Clinical Endocrinology 201277 343-350. (https://doi.org/10.1111/j.13652265.2012.04434.x)

115 Rahimi-Ardabili H, Gargari BP \& Farzadi L. Effects of vitamin D on cardiovascular disease risk factors in polycystic ovary syndrome women with vitamin D deficiency. Journal of Endocrinological Investigation 201336 28-32. (https://doi.org/10.3275/8303)

116 He C, Lin Z, Robb S \& Ezeamama A. Serum vitamin D levels and polycystic ovary syndrome: a systematic review and meta-analysis. Nutrients 20157 4555-4577. (https://doi.org/10.3390/nu7064555)

117 Krul-Poel YHM, Snackey C, Louwers Y, Lips P, Lambalk CB, Laven JS \& Simsek $\mathrm{S}$. The role of vitamin $\mathrm{D}$ in metabolic disturbances in polycystic ovary syndrome: a systematic review. European Journal of Endocrinology 2013169 853-865. (https://doi.org/10.1530/EJE-13-0617)

118 Sprung VS, Cuthbertson DJ, Pugh CJ, Aziz N, Kemp GJ, Daousi C, Green DJ, Cable NT \& Jones H. Exercise training in polycystic ovarian syndrome enhances flow-mediated dilation in the absence of changes in fatness. Medicine and Science in Sports and Exercise 201345 2234-2242. (https://doi.org/10.1249/MSS.0b013e31829ba9a1)

119 Domecq JP, Prutsky G, Mullan RJ, Hazem A, Sundaresh V, Elamin MB, Phung OJ, Wang A, Hoeger K, Pasquali R, et al. Lifestyle modification programs in polycystic ovary syndrome: systematic review and metaanalysis. Journal of Clinical Endocrinology and Metabolism 201398 4655-4663. (https://doi.org/10.1210/jc.2013-2385)

120 Thomson RL, Brinkworth GD, Noakes M, Clifton PM, Norman RJ \& Buckley JD. The effect of diet and exercise on markers of endothelial function in overweight and obese women with polycystic ovary syndrome. Human Reproduction 201227 2169-2176. (https://doi. org/10.1093/humrep/des138)

121 Dantas WS, Murai IH, Perandini LA, Azevedo H, Moreira-Filho CA, Camara NO, Roschel H \& Gualano B. Acute exercise elicits differential expression of insulin resistance genes in the skeletal muscle of patients with polycystic ovary syndrome. Clinical Endocrinology 201786 688-697. (https://doi.org/10.1111/cen.13307)

122 Nestler JE \& Jakubowicz DJ. Decreases in ovarian cytochrome P450c17 $\alpha$ activity and serum free testosterone after reduction of insulin secretion in polycystic ovary syndrome. New England Journal of Medicine 1996335 617-623. (https://doi.org/10.1056/ NEJM199608293350902)

123 Kirpichnikov D, McFarlane SI \& Sowers JR. Metformin: an update. Annals of Internal Medicine 2002137 25-33. (https://doi. org/10.7326/0003-4819-137-1-200207020-00009)

124 Diamanti-Kandarakis E, Spina G, Kouli C \& Migdalis I. Increased endothelin-1 levels in women with polycystic ovary syndrome and the beneficial effect of metformin therapy. Journal of Clinical Endocrinology and Metabolism 200186 4666-4673. (https://doi. org/10.1210/jcem.86.10.7904)

125 Diamanti-Kandarakis E, Alexandraki K, Protogerou A, Piperi C, Papamichael C, Aessopos A, Lekakis J \& Mavrikakis M. Metformin administration improves endothelial function in women with

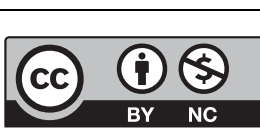

This work is licensed under a Creative Commons Attribution-NonCommercial 4.0 International License. 
polycystic ovary syndrome. European Journal of Endocrinology 2005 152 749-756. (https://doi.org/10.1530/eje.1.01910)

126 Yang PK, Hsu CY, Chen MJ, Lai MY, Li ZR, Chen CH, Chen SU \& Ho HN. The efficacy of 24-month metformin for improving menses, hormones, and metabolic profiles in polycystic ovary syndrome. Journal of Clinical Endocrinology and Metabolism 2018103 890-899. (https://doi.org/10.1210/jc.2017-01739)

127 Patel R \& Shah G. Effect of metformin on clinical, metabolic and endocrine outcomes in women with polycystic ovary syndrome: a meta-analysis of randomized controlled trials. Current Medical Research and Opinion 201733 1545-1557. (https://doi.org/10.1080/03 007995.2017.1279597)

128 Naderpoor N, Shorakae S, de Courten B, Misso ML, Moran LJ \& Teede HJ. Metformin and lifestyle modification in polycystic ovary syndrome: systematic review and meta-analysis. Human Reproduction Update 201622 408-409. (https://doi.org/10.1093/humupd/ dmv063)

129 Ibáñez L, Díaz M, Sebastiani G, Marcos MV, López-Bermejo A \& de Zegher F. Oral contraception vs insulin sensitization for 18 months in nonobese adolescents with androgen excess: posttreatment differences in C-reactive protein, intima-media thickness, visceral adiposity, insulin sensitivity, and menstrual regularity. Journal of Clinical Endocrinology and Metabolism 201398 E902-E907. (https:// doi.org/10.1210/jc.2013-1041)

130 Jensterle M, Kravos NA, Pfeifer M, Kocjan T \& Janez A. A 12-week treatment with the long-acting glucagon-like peptide 1 receptor agonist liraglutide leads to significant weight loss in a subset of obese women with newly diagnosed polycystic ovary syndrome. Hormones 201514 81-90. (https://doi.org/10.14310/horm.2002.1576)

131 Okerson T \& Chilton RJ. The cardiovascular effects of GLP-1 receptor agonists. Cardiovascular Therapeutics 201230 e146-e155. (https://doi. org/10.1111/j.1755-5922.2010.00256.x)
132 Vyas AK, Yang K-C, Woo D, Tzekov A, Kovacs A, Jay PY \& Hruz PW. Exenatide improves glucose homeostasis and prolongs survival in a murine model of dilated cardiomyopathy. PLOS ONE 20116 e17178. (https://doi.org/10.1371/journal.pone.0017178)

133 Hoang V, Bi J, Mohankumar SM \& Vyas AK. Liraglutide improves hypertension and metabolic perturbation in a rat model of polycystic ovarian syndrome. PLOS ONE 201510 e0126119. (https://doi. org/10.1371/journal.pone.0126119)

134 Elkind-Hirsch K, Marrioneaux O, Bhushan M, Vernor D \& Bhushan R. Comparison of single and combined treatment with exenatide and metformin on menstrual cyclicity in overweight women with polycystic ovary syndrome. Journal of Clinical Endocrinology and Metabolism 200893 2670-2678. (https://doi. org/10.1210/jc.2008-0115)

135 Jensterle M, Goricar K \& Janez A. Add on DPP-4 inhibitor alogliptin alone or in combination with pioglitazone improved $\beta$-cell function and insulin sensitivity in metformin treated PCOS. Endocrine Research 201742 261-268. (https://doi.org/10.1080/07435800.2017.1294602)

136 Bajuk Studen K, Šebeštjen M, Pfeifer M \& Preželj J. Influence of spironolactone treatment on endothelial function in non-obese women with polycystic ovary syndrome. European Journal of Endocrinology 2011164 389-395. (https://doi.org/10.1530/EJE-100709)

137 Malik SM \& Traub ML. Defining the role of bariatric surgery in polycystic ovarian syndrome patients. World Journal of Diabetes 2012 3 71. (https://doi.org/10.4239/wjd.v3.i4.71)

138 Escobar-Morreale HF, Santacruz E, Luque-Ramírez M \& Botella Carretero JI. Prevalence of 'obesity-associated gonadal dysfunction' in severely obese men and women and its resolution after bariatric surgery: a systematic review and meta-analysis. Human Reproduction Update 201723 390-408. (https://doi.org/10.1093/humupd/ dmx012)

Received in final form 14 May 2018

Accepted 29 May 2018

Accepted Preprint published online 29 May 2018 http://www.endocrineconnections.org https://doi.org/10.1530/EC-18-0129 (c) 2018 The authors Published by Bioscientifica Ltd

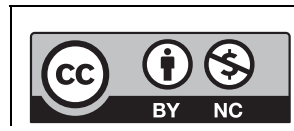

This work is licensed under a Creative Commons Attribution-NonCommercial 4.0 International License. 